\title{
THE LEGALITY OF A LIVING TRUST AS AN INSTRUMENT FOR ISLAMIC WEALTH MANAGEMENT: A MALAYSIAN PERSPECTIVE
}

\author{
Akmal Hidayah Halim*
}

\begin{abstract}
At present, the use of living trust is advocated as one of the best mechanisms to be considered for Islamic wealth management in Malaysia. Whilst the purpose of creating a living trust is to benefit the beneficiary, the settlor retains complete control and enjoyment over the trust property during his lifetime, and the beneficiary will only benefit the trust property after the death of the settlor. This instrument has been legally recognised to be applicable to Muslims in Malaysia and is enforceable against the settlor or his estate, irrespective of whether or not possession of the property was given to the beneficiary during the lifetime of the settlor or whether or not the settlor enjoyed the property during his lifetime. This situation is inconsistent with the rule of Islamic law on gift (hibah) and succession, especially when the beneficiary is a person who has the legal capacity to own property and who may be one of the legal heirs of the deceased-settlor. This
\end{abstract}

Assistant Professor, Ahmad Ibrahim Kulliyyah of Laws, International Islamic University Malaysia. 
article seeks to examine the execution of living trust by Muslims in Malaysia so that the rights of the beneficiaries under such trust are legally ascertained according to the Islamic law.

Keywords: living trust, wealth management, hibah, succession, gift inter vivos, life interest, Islamic trust, wașiyyah, trustee, Malaysian law.

\begin{abstract}
ABSTRAK
Pada masa sekarang, penggunaan amanah hidup dihujahkan sebagai salah satu kaedah terbaik untuk dipertimbangkan bagi pengurusan kekayaan Islam di Malaysia. Walaupun tujuan membuat amanah hidup adalah untuk memanfaatkan benefisiari, setlor kekal mempunyai kawalan penuh dan keseronokan ke atas harta amanah semasa hayatnya, dan benefisiari akan memanfaatkan harta amanah tersebut hanya selepas kematian setlor. Instrumen ini telah diiktiraf menurut undang-undang sebagai terpakai ke atas orang Muslim di Malaysia dan boleh dikuatkuasakan terhadap setlor atau harta pusakanya, tanpa mengambil kira sama ada milikan harta diberi kepada benefisiari semasa hayat setlor atau sama ada setlor menikmati harta tersebut semasa hayatnya. Keadaan ini tidak selaras dengan hukum undang-undang Islam tentang hibah dan pewarisan, terutamanya apabila benefisiari adalah seorang yang mempunyai keupayaan undangundang untuk memiliki harta dan yang boleh jadi salah seorang waris sah kepada setlor si mati. Makalah ini meneliti pelaksanaan amanah hidup oleh orang Muslim di Malaysia dan sama ada hak benefisiari di bawah amanah sedemikian adalah boleh dipastikan menurut undang-undang Islam.
\end{abstract}

Kata kunci: amanah hidup, undang-undang Islam, hibah, pewarisan. 


\section{INTRODUCTION}

In any legal system of succession, the fundamental consideration is the extent to which an individual has the personal right to determine the devolution of his property after his death. ${ }^{1}$ The Muslims, are governed by the Islamic law of succession which is firmly based on the revelation in the Qur'ān. However, some individuals still consider that the Islamic law of succession would in their particular circumstances, limit their freedom of choosing their own successors and produce inappropriate distribution of their estate. Hence, several alternatives have been utilized to avoid the application of the Islamic law of succession to some or all of the property. In this context, the use of living trust is advocated as one of the alternatives to be considered for Islamic wealth management in Malaysia which permits a person to transfer ownership of his property from his individual name into a trust controlled by him. This instrument permits the person who creates such a trust 'the settlor' to retain complete control and enjoyment over the trust property during his lifetime, while securing the transfer of the property to the chosen successor after his death in a manner which completely avoids the law of succession.

As a mere avoidance of the law of succession does not invalidate an instrument which is otherwise valid under the Islamic law, ${ }^{2}$ there is a great need to determine the validity of a living trust as an instrument for Islamic estate planning. This is due to the reason that its constitution seems to be inconsistent with the Islamic law on gift and succession, especially when the beneficiary is a person who has the legal capacity to own property and who may be one of the legal heirs of the deceasedsettlor. Hence, this paper aims at examining the execution of living trusts by Muslims in Malaysia so that the rights of the beneficiaries under such a trust are legally ascertained according to the Islamic law. The discussion will focus on the constitution of living trust and the applicable law relating to trust in Malaysia. The trust in Islam together with the Islamic law on gift and succession will also be discussed in order to identify the

\footnotetext{
$1 \quad$ Noel J. Coulson, Succession in the Muslim Family, Cambridge Eng: University Press, 1971, p. 1.

$2 \quad$ Lucy Caroll, "Life Interest and Inter-Generational Transfer of Property Avoiding the Law of Succession," Islamic Law and Society, Vol. 8, No. 2, 2001, p. 254.
} 
inconsistency and the scope for the use of living trust as an instrument for Islamic wealth management in Malaysia.

\section{CONSTITUTION OF LIVING TRUST}

Living trust is a form of gift inter vivos created during the lifetime of the settlor and remains active thereafter. ${ }^{3}$ It is completely constituted where the settlor (the owner of the trust property) appoints a trustee, or in circumstances where the settlor declares himself as a trustee to hold the property on trust for the beneficiary. The effect of such a trust is that the trust property will no longer belong to the settlor's estate and it is irrevocable unless the power of revocation is reserved when constituting the trust. ${ }^{4}$ The trust property will however, result back to the settlor if the beneficiary pre-deceased the settlor.

A classic statement on the law relating to the requirements for the constitution of a trust was made by Turner L.J. in Milroy v. Lord: ${ }^{5}$

"I take the law of this Court to be well settled, that, in order to render a voluntary settlement valid and effectual, the settlor must have done everything which, according to the nature of the property comprised in the settlement, was necessary to be done in order to transfer the property and render the settlement binding upon him. He may, of course, do this by actually transferring the property to the persons for whom he intends to provide, and the

$3 \quad$ In Malaysia, there are only three ways in which a gift inter vivos may be legally made namely, by an outright transfer of the property to the intended donee or by a transfer of the property absolutely to trustees to hold on trust for the donee or by the owner declaring himself as a trustee for the donee. See Lee Ing Chin \& Ors v. Gan Yook Chin \& Anor [2003] 2 CLJ 19 at p. 63.

$4 \quad$ Mary George, Malaysian Trust Law, Selangor: Pelanduk Publication, 1999, p. 78; See also David J. Hayton, Underhill and Hayton law relating to trusts and trustees, $15^{\text {th }}$ Edition, Butterworths, p. 125.

5 (1862) 4 De G.F. \& J. 264 at 274-275. 
provision will then be effectual, ${ }^{6}$ and it will be equally effectual if he transfers the property to a trustee for the purposes of the settlement, or declares that he himself holds it in trust for those purposes;" (emphasis added)

The above statement establishes that a trust may be constituted either by a conveyance where the settlor effectively transfers the property to the trustees and declaring the trust upon which the trustees are to hold such property, or by the settlor declaring that the property vested in him is to be held by him on trust.

Where the settlor appoints a trustee, the trust will be completely constituted only when the trust property is validly transferred to and vested on the trustees by the appropriate formal method laid down by law. In cases where the settlor declares that the property vested in him is to be held by him on trust, the legal title to the property is retained by the settlor who himself becomes the trustee. On the declaration of trust, the following statement by Sir George Jessel MR in the case of Richards

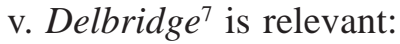

"...the legal owner of the property may, by one or other of the modes recognized as amounting to a valid declaration of trust, constitute himself a trustee, and without an actual transfer of the legal title, may so deal with the property as to deprive himself of its beneficial ownership, and declare that he will hold it from that time forward on trust for the other person. It is true he need not use the words, 'I declare myself a trustee' but he must do something which is equivalent to it, and use expressions which have that meaning; for however anxious the Court may be to carry out a man's intention, it is not at liberty to construe words otherwise than according to their proper meaning...for a man to make himself a trustee

\footnotetext{
$6 \quad$ This kind of voluntary settlement is in the form of gift inter vivos by an outright transfer.

$7 \quad$ (1874) LR 18 Eq 11.
} 
there must be an intention to become a trustee..." (emphasis added).

Based on the above statement, it can be inferred that if the settlor unequivocally declares himself as a trustee, there will be a manifestation of his intention to be the trustee to hold the property on trust.

\section{THE APPLICABLE LAW OF TRUST IN MALAYSIA}

The decision of the Court of Appeal in the case of TM Feroze Khan \& Ors v. Meera Hussain TM Mohamed Mydin ${ }^{8}$ establishes that the applicable law relating to matters on trust in Malaysia is the civil law regardless of whether the parties are Muslims or non-Muslims. In this case, the deceased owned a piece of land on which were erected nine houses that were rented out to tenants. During his lifetime, the deceasedsettlor had transferred and registered the property to himself as trustee for the benefit of the then his eight-year old son, the respondent. Simultaneously with that, the deceased also executed a trust deed declaring himself as holding the property in trust for the latter. The deceased did not during his lifetime make any attempt to revoke the memorandum of transfer or trust deed in question. The facts also showed that after the deceased's death, the respondent obtained an ex parte vesting order from the High Court vesting the property in his own name. The appellants, the deceased's children from his other marriage, argued that the purported gift of the property was void under Islamic law and ought to belong to the deceased's estate as no valid gift could have been effected since the property, having been rented out, was not in the (physical) possession of the deceased, and neither was such possession handed to the respondent during his lifetime.

It was held that though under the Islamic law, the delivery of possession of the property by the donor is an essential element to constitute a complete gift, this case fell under the exception to the general rule

[2006] 3 CLJ 616. See also the case of Wan Naimah v. Wan Mohamad Nawawi [1974] 1 MLJ 41 where the court applied trust law and not Islamic law to enforce a gift by an oral declaration of trust involving Muslim family. Similar application was made in Re Man bin Mihat, Deed [1965] 2 MLJ 1. 
since this was the case of a gift from a father to his minor son in which case, the delivery of possession was not necessary at all. The law would be satisfied without change of possession and would presume subsequent holding of the property to be on behalf of the minor. All that would be necessary was a real and bona fide intention to make a gift. $^{9}$ In this case, the deceased's bona fide intention to give the property as a gift to the respondent was manifestly clear and unequivocal as the deceased had effected a legal transfer of the property on trust in favour of the respondent and thereby transferred the legal possession of the property to the respondent. As this was the only means for effecting transfer under the National Land Code 1965, the deceased had done everything possible within his means to deliver legal possession in line with statutory provisions on the subject matter.

It was further held that the applicable law in the above case was the civil law of trust and that it would apply regardless of whether the parties are Muslims or non-Muslims. Hence, as long as the trust was completely constituted according to the requirements under the civil law of trust, it was enforceable against the deceased or his estate, irrespective of whether or not possession of the property was given to the respondent during the life time of the deceased and whether or not the deceased received and declared the rental as his personal income. In other words though the requirements governing gifts under Islamic law might not be fulfilled, such an instrument would still be legally recognised under the Malaysian Law on trust.

At this point, it is pertinent to note that the best way of proving genuine intention to make a gift is to establish that the transfer of the gift was actually carried into effect, that the declaration had been acted upon, and that the donor had done everything which was appropriate to implement the transfer of the gift to the beneficiary. The surrounding circumstances may however show that the alleged gift was not intended to operate as a transfer to the donee. ${ }^{10}$ It is therefore submitted that if the settlor continues to treat the engifted property as his own, such a situation would fall under the surrounding circumstances which may rebut

\footnotetext{
$9 \quad$ See also Lucy Caroll, "Definition and Interpretation of Muslim Law in South East Asia: The Case of Gifts to Minors," Islamic Law and Society, BRILL, Vol. 1, No.1, 1994, p. 88. Ibid, p. 89.
} 
the creation of the trust. It is very unfortunate that the case of TM Feroze Khan did not deal with the requirements of Islamic law on gift in details and that the case was decided based on the English law of trust. It is also unfortunate, with due respect, that the decision relating to the satisfaction of the requirements of a valid gift under Islamic law, had not been made by the Syariah Court as the jurisdiction to deal with matters on trust lies in the Civil Court.

\section{TRUST IN ISLAM}

The concept of Islamic trust requires a person entrusted with such trust to look after the trust property just as he would look after and protect his own property. The creation of Islamic trust as one of the instruments for estate planning generally involves the appointment of trustee who is duty bound to look after and manage the trust property according to the terms and conditions as stipulated by the person who creates the trust (the settlor). This is evident in the following verses of the Qur'ān:

"Allah does command you to render back your trust to those to whom they are due..."

(Sūrah Al-Nisā'(4): 58)

"O ye that believe! Betray not the trust of Allah and the Apostle, nor misappropriate knowingly things entrusted to you"

(Sūrah Al-Anfāl (8): 27)

"And if one of you deposits in trust a thing with another, let the trustee (faithfully) discharge his trust, and let him fear his Lord"

(Sūrah Al-Baqarah (2): 83)

In Islam, the appointment of a trustee normally exists in the form of wakälah or agency which arises when one person authorises another to replace him in the exercise of his civil rights. An appointment of a trustee may also be made by way of wișayah which refers to the appointment or entrustment of a person for the administration of the appointer's estate and the property of his minor children after his death. 
Trusteeship may also exist in the form of wadī'ah that allows a person to keep the wealth or assets belonging to oneself with another person for safekeeping purposes. In cases of waqf, Islamic Religious Council of each state in West Malaysia is appointed as the sole trustee of waqf property. The appointment is by operation of law, thus invalidating any appointment of trustee other than the Council.

Self-appointment as trustee in Islam may only exist in cases of gifts to a minor or unsound person who has no legal capacity to hold property. In such cases, someone has to accept the property on behalf of the minor or of the unsound person. The most obvious person to perform the task is the person recognized as the legal guardian of the person's property namely, (in sequence) father, father's executor, paternal grandfather or his executor. ${ }^{11}$ In cases of a minor's property, it will be transferred upon the minor reaching the age of majority. In Malaysia, the age of majority is 18 years as provided by section 2 of the Age of Majority Act 1971. The trustee will thereafter be discharged from his duty to manage and administer the trust property. Nevertheless, in cases of unsound person, the trustee is under a duty to manage and administer the former's property throughout his or her lifetime.

It is therefore submitted that in Islam, once a trust is created, the property is no longer the settlor's and the entrusted person will administer and manage the trust property according to the terms and conditions of the trust even in cases of self-appointment as trustee. The trustee is charged with a great responsibility to guard the interest of the person on whose behalf he holds the trust and to render back the property and accounts when required according to the terms of the trust.

\section{GIFT IN ISLAM}

Any gratuitous transfer of property that is made with the intention of obtaining a recompense in the hereafter is called alms. If the transfer is made to a donee in order to show one's respect to him, it is a present or a gift inter vivos (hibah). ${ }^{12}$ However, for a present, neither offer (ijjajb)

\footnotetext{
$11 \quad$ Lucy Caroll, "Definition and Interpretation of Muslim Law in South East Asia: The Case of Gifts to Minors," pp. 87-88.

12 Al-Nawawī, Minhāj-al-Tãalibìn, A manual of Muhammadan law according to the school of Shäfi $i$, translated by E.C. Howard, Law
} 
nor acceptance (qabül) is required as it is enough that the object is brought by the donor and taken possession of by the donee. The disposition of property as a present differs from the gift inter vivos or hibah in the sense that the requirement for offer and acceptance is of the essence to the latter. For a hibah, it is an essential condition that offer and acceptance be made in explicit terms in order to validate such a gift. ${ }^{13}$

Nonetheless, even if there is an offer and acceptance, the hibah is still not effective unless the delivery of the possession (qabd ) has taken place. ${ }^{14}$ In Tengku Haji Jaafar Ibni Almarhum Tengku Muda Ali \& Anor v. Government of Pahang, ${ }^{15}$ the requirement for the possession was stated as follows:

"As regards gift of land, whether it be to a Muslim
or to a non-Muslim the gift will not be valid unless
the donee takes possession of the gift of land at the
time the gift is made. In other words, a gift will
transfer the ownership of the subject matter of the
gift to the donee only upon the latter taking
possession of it."

Accordingly, the three important requirements, namely offer, acceptance and taking possession must take place to effect a hibah. Unless and until possession is taken by the donee, the property remains entirely at the disposal of the donor. If therefore, a donor makes an offer of a gift which is accepted by the donee, without the delivery of possession, then on the death of the donor, the property will pass to the donor's heirs. ${ }^{16}$ On the other hand, upon the delivery of the possession, the property will be the donee's and will fall under his estate on his death.

\footnotetext{
Publishing Co., 1977, p. 234.

Ibid., p. 234.

David Pearl, A textbook on Muslim law, Croom Helm, 1979, p. 158; The delivery of the gift is a condition of validity: Jamal J Nasir, The Islamic law of personal status, Graham \& Trotman, 1990, p. 282.

$15 \quad$ [1987] 2 MLJ 74 at 131.

16 David Pearl, A textbook on Muslim law, p. 158. Some jurists however, take the view that the gift passes to the ownership of the donee on the completion of the contract, maintaining that taking possession thereof is not a condition of validity in contracts such as in the case of sale.
} 


\section{ISLAMIC LAW OF SUCCESSION}

There are two means available for a person to be entitled to the deceased's estate upon the latter's death, namely, by the intestate succession or by way of testate succession.

The intestate succession is commonly referred to as 'faräid' which denotes the shares of inheritance allotted to various relatives by the Qur'an. It is a set of laws defining exactly the share of the entitled legal heirs of a deceased person. Intestate succession is automatically invoked upon death and it does not carry with it any notion of a necessary recourse to a scheme of succession invoked only because the deceased has failed in his duty personally to arrange the devolution of his property. Accordingly, the disposition of property by way of testate succession or in accordance with the wishes of the deceased is of secondary importance as the central core of the system of succession is formed by the compulsory rules of faräid designed for the material benefit of the legal heirs. ${ }^{17}$

A disposition of property by way of a wasiyyah is also known as testamentary disposition or testate succession. It is a declaration of a person made during his lifetime with respect to his property or benefit thereof, to be carried out after his death. It follows therefore, as the will is effective only after the death of the testator, the transfer of the property will only take effect on such death. Consequently, no claim can be made by the beneficiaries of a wasiyyah before the testator's death and the testator is free to deal with the property during his lifetime.

Nevertheless, the making of a wașiyyah by a Muslim is subject to some limitations as far as the beneficiary is concerned and also as to the quantum of the wașiyyah. The limitation regarding the beneficiary is

Accordingly, if the donor or donee dies before delivery, then the gift will not be void because once the contract has taken place, the gift becomes the property of the donee. Abū Haniffah and Shäfi $\bar{l}$, however, are of the opinion that taking possession is a condition for the validity of the gift: Jamal J. Nasir, at 285-286. Moreover, by the "no consideration" component, gift differs from sale.

17 Noel J. Coulson, Succession in the Muslim Family, Cambridge Eng: University Press, 1971, p. 2. 
that the person must not be the legal heir ${ }^{18}$ of the testator. This is based on the hadith reported by Abū Umāmah:

I heard the Prophet (s.a.w) said: "Allah has already given to each entitled relative his proper entitlement. Therefore, no bequest in favour of a legal heir." 19

The reason for the limitation is that it would amount to giving preference to some inheritors over others, thus defeating the policy of the intestate succession which has allocated fixed portions to each heir in the inheritance and would also give rise to disputes. However, the majority of jurists opined that such a disposition is valid if unanimously approved by all the other legal heirs. ${ }^{20}$ Such bequest is not void but merely predicated and conditional upon the required consent of the other heirs. If the other heirs assent to it, the bequest shall be effective.

As for the quantum of the wasiyyah, it is only applicable in cases of a wassiyyah in favour of a non-legal heir. This is understandable as the wasiyyah in favour of a legal heir will be invalid regardless of the quantum, unless if it is consented by other heirs. The quantum of the wasiyyah should not exceed one-third of the net estate. This is because the testator is not allowed to defeat the entitlement of the legal heirs to at least twothirds of the estate by such will, however meritorious his purpose is. The ruling on the quantum of bequest that it should not be more than one-

$18 \quad$ As a will speaks from the time of death, the ban operates only against one who is a legal heir of the testator at the time of the latter's decease. Accordingly, a will made in favour of a person who is an heir of the testator at the time the will is made, but due to supervening circumstances is not his heir at the time of death is not caught by the ban. This is the case, for example, where a husband bequeaths property to his wife and subsequently the couple are effectively divorced before the husband's death; Noel J. Coulson, Succession in the Muslim family, p. 241.

19 Al-Bukhārī, Sahịh al-Bukhārī, translated by Muhammad Muhsin Khan, Kazi Publication, vol. 4, 1979, p. 6. Al-Nawawī, Maḥy al-Dīn Abī Zakarīyya Yaḥya ibn Sharaf, Minhāj alTălibin: A manual of Muhammadan law according to the school of Shafi 'i, p. 260; See also Abdul Aziz Mohammed Zaid, The Islamic law of bequest, Scorpion Publishing Ltd, 1986, p. 70. 
third is derived from the report by the Prophet's companion, Sa 'ad ibn Abī Waqqās who said:

The Prophet (s.a.w) came to visit me in my sickness. I was then at Mecca and did not like to die at a place from where I had migrated. The Prophet of God (s.a.w) said: "God shall have mercy on Ibn Nafra'." I said to the Prophet (s.a.w), "O Prophet (s.a.w)! I am wealthy and my only heir is my daughter. Permit me that I make a will of my entire property." He said, "No". I said, "Should I make a will of twothirds of my property?" He said, "No." I said, "Permit me for a third." The Prophet (s.a.w) replied, "You may make a will of a third, although this is also too much. To leave after you your heirs well to do is better than you leave them poor and in want whilst others meet their needs." 21

\section{INCONSISTENCY BETWEEN THE LIVING TRUST AND THE ISLAMIC LAW ON GIFT AND SUCCESSION}

Whilst the purpose of creating a living trust is to benefit the beneficiary, the settlor retains complete control and enjoyment over the trust property during his lifetime. A self-declaration as a trustee by the Muslim-settlor seems to have turned out to be an instrument to avoid the Islamic law of succession as the terms of the trust may provide that on the death of the settlor, the trust property will be transferred to the beneficiary of such trust. On the settlor's death, the trust property will be transferred to the beneficiary accordingly and the property is no longer considered as part of the deceased-settlor's estate. Consequently, the other legal heirs cannot claim to be entitled to the property anymore.

It may be suggested that there are few reasons for a Muslim to resort to such a trust in disposing of his property. One of them is to avoid the property being subject to the Islamic law of succession as it is not unusual that the beneficiary of such a trust is a person who is also entitled 
to the settlor's estate on his death. By creating such a trust, the settlor may favour one legal heir over another. As such, the beneficiary of the trust will be entitled not only to the trust property but also to the fixed portion provided by the Islamic law of intestate succession. The following statement by Suffian J. (as he then was) in the case of Re Man bin Mihat ${ }^{22}$ proves that the creation of this kind of trust was a common practice among the Muslims even back in 1965. He said:

"Indeed it is quite common for a Muslim to buy land
for his minor children and have himself registered
in the Land Office records as trustee, though the
effect would be to augment the share received by
those children in his property after his death. During
his lifetime the land is trust property and his death
does not alter its character, for thereafter the land
remains trust property and his administrator holds it
for the purposes of the trust." (emphasis added)

Although the instrument of gift inter vivos or hibah in Islam could also be used to evade the application of the rules of succession by reducing the estate which would ultimately fall under the deceaseddonor's estate, the requirement that the donor must denude himself of the property and pass full title and possession immediately to the donee makes such an instrument a less viable option. The donor might have an intention to make a hibah but due to the risk that such property might later on be disposed of by the donee, the donor would definitely opt to reduce the risk by resorting to a living trust which provides for the donor's life interest and for the beneficiary absolutely on the former's death.

It is submitted that the concept of living trust is inconsistent with the Islamic rule on gift inter vivos as the settlor retains the control and enjoyment over the trust property during his lifetime. This is especially so in cases of self-declaration as trustee where there is no immediate delivery of the possession of the property to the beneficiary. It is also in conflict with the Islamic law of succession since the transfer of the trust property will be made to the beneficiary only after the settlor's death, giving the settlor the right to augment the share received by the legal 
heirs after his death. This kind of instrument also defeats the creation of trust in Islam since the settlor does not actually divest himself from the property and that the beneficiary may comprise other than the minors and those who are not legally capable of holding property.

\section{CONCLUSION}

An instrument created by an irrevocable, living express trust is deemed to be a gift (hibah) given by a Muslim during his lifetime and does not constitute part of his estate at the time of his death. In order to harmonise the use of living trust as an instrument for Islamic estate planning, such a trust should be declared irrevocable and the settlor should not retain any interest or benefit to qualify it as an inter vivos gift. In cases of selfdeclaration as trustee, the settlor should have absolutely parted with the interest that had been his up to the time of the declaration. He must deal with the property so as to divest himself from the beneficial ownership over the property. Otherwise, the settlor may be liable for breach of trust. Similarly, if the settlor has decided to execute a trust in favour of a beneficiary, he should no longer be free to claim or enjoy the property as if no trust has ever been created. A purported gift by way of living trust is really no gift at all if the settlor has no intention of immediately divesting himself of the proprietary interest and control over the property.

Though the validity of living trust under the civil law has been legally established as one of the estate planning instruments in Malaysia, it is submitted that for the Muslims, such an instrument is invalid due to its inconsistency with the Islamic law on hibah and succession. Unless it is a pure trusteeship, it should not be given legal recognition as an instrument for Islamic estate planning in Malaysia. If this is allowed, it will definitely become a tactic of avoiding the Islamic law of succession in order to confer a person with a right to choose his or her own successor of the estate after the person's death. It is quite intimidating as this might be the reason for the ignorance of the Islamic law on succession as reported by Ibn Mas'ud that the Prophet (s.a.w) had said:

"Learn (Study) the knowledge of succession and teach it because I shall be taken away (die), and so is the knowledge. Therefore, the twaddle will emerge until a conflict of two persons happens over the 
succession, yet there is not any person available to solve their problems."

Hence, the use of the living trust among Muslims in Malaysia must be given a greater caution in order to ensure that this instrument is consistent with the Islamic law. 